\title{
The Role of Central Asian Traditions in Mongolian Fine Arts
}

\author{
Kseniya Aleksandrovna Melekhova, ${ }^{\dagger}$ Yelena Yurievna Lichman, 'Z Zhanaykhan Erkin', Abdrashid
} Iskakovich Raimbergenov' and Adilgali Abdigaliyevich Sagimbayev ${ }^{\Upsilon}$

\section{Abstract}

The article considers the role of Central Asian traditions in the formation and development of Mongolian fine arts. The authors reveal the significance of various factors for the formation of the original stylistics, which manifested itself in the methods, techniques and pictorial means typical of Mongolian art. The article defines the role of Indian artistic traditions in the development of Mongolian fine arts. The authors claim that Mongolian religious painting on scrolls is a bright artistic phenomenon based on the strict canon developed in India and inherited by many cultures of Asia. The means of artistic depiction, iconography, a system of proportions, borrowed and modified by the Mongols, had been developed in the cradle of Indian civilisation. The purpose of the article is to study the features of Mongolian fine arts on the basis of ethnic traditions, as well as to consider this phenomenon using the example of traditional and contemporary painting.

Multiculturalism conditioned by the polyethnic nature of the region played an important role in the history of Mongolian culture. The renewal of ethnocultural experience is related to the artistic traditions brought from India, Tibet and China, but in Mongolian art, there is no predominance of any forms of other cultures. Hence, the art is original and has its unique features. As a result of the combination of the ornamental pictorial technique of nomadic cultures with the painting techniques of sedentary peoples, an artistic style based on the Buddhist canon, supplemented by original ethnocultural elements, was formed. In the process of mastering and developing the artistic experience based on the traditions of planar painting, icon painting, arts and crafts, folklore, a new art direction "Mongol Zurag" appeared in the 20th century. The creative method of modern masters proves that while working in various trends, genres, techniques, individual manners, they preserve and develop national traditions in painting. Consequently, the preservation of the artistic-aesthetic heritage of the ethnos has a positive effect on fine arts and the vitality of culture in general.

Keywords: Artistic tradition, Canon, India, Mongolian Fine Arts, Role of Central Asia

\footnotetext{
${ }^{\dagger}$ Candidate of Art History Sciences (PhD), Assistant Professor, Altai State University, 61 Lenina Ave., Barnaul, Russia, Email: gurkina-22@mail.ru

'Doctor of Philosophy (PhD), Assistant Professor of the Department of Theory and Methodology of Music Education, Pavlodar State Pedagogical University, 60 Mira St., Pavlodar, Kazakhstan

'Doctor of Philosophy (PhD), Assistant Professor of the Department of Theory and Methodology of Music Education, Pavlodar State Pedagogical University, 60 Mira St., Pavlodar, Kazakhstan

"Candidate of Art History Sciences, Senior Lecturer of the Department of Music Education, K. ZhubanovAktobe Regional State University, 34 AliiMoldagulovoi St., Aktobe, Kazakhstan

ICandidate of Pedagogical Sciences (PhD), member of the Union of Designers of Kazakhstan K. Zhubanov Aktobe Regional State University, 34 Alii Moldagulovoi St., Aktobe, Kazakhstan

(C) 2018 Melekhova et al. This is an Open Access article distributed under the terms of the Creative Commons Attribution License (http://creativecommons.org/licenses/by/2.0), which permits unrestricted use, distribution, and reproduction in any medium, provided the original work is properly cited.
} 


\section{Introduction}

The article is devoted to the study of traditions in Mongolian fine arts of the $20^{\text {th }}$ and the beginning of the $21^{\text {st }}$ centuries. The relevance of this research is explained by the increased interest of contemporary art history in the problems of ethnic self-awareness, which is an important characteristic of creative individuality. This worldview paradigm is characteristic of the world art in general; it was clearly reflected in Mongolian fine arts. Interest in Mongolian culture and art grew with the expansion of scientific outlook. The historiography of this problem dates back to the end of the $18^{\text {th }}-19^{\text {th }}$ centuries. The expeditions organised by the Russian Academy of Sciences played an important role and prominent amongst these were:the First Central Asian (Mongolian) expedition (November 1870 - October 1873); the First Mongolian (Tarbagatai) Expedition (July 1876 January 1878); the Second Mongolian Expedition (June 1879 - June 1880); the Third Expedition (First Chinese-Tibetan, TangutTibetan or Gansui) (August 1883 - October 1886) and many others. N.Ya. Bichurin, E.F. Timkovsky, N.M. Przhevalsky, G.N. Potanin, A.V. Potanina, M.V. Pevtsov, A.M. Pozdneev, P.K. Kozlov and other scientists-travellers, who made a significant contribution to Mongolian studies, took part in these expeditions. Participants in the expeditions compiled extensive collections of manuscripts, books, travel sketches, works of Buddhist painting, sculpture, arts and crafts, which were sent to state collections (Puchkovsky, 1960). The Russian researcher A.M. Pozdneev studied Mongolian culture. In his work "Sketches of the everyday life of Buddhist monasteries and the Buddhist clergy in Mongolia in connection with the relationship of the latter with the people" (1993), significant attention is paid to Mongolian icons with the detailed description of characters, background, location, poses, gestures, etc. The author distinguishes mandalas depicting the locations of idols of Buddha as "special drawings" (Pozdneev, 1993). $A$ researcher, philosopher, traveller and artist N.K. Roerich played an enormous role in the study and popularisation of fine arts of the Mongols. During the expeditions, he gathered collections of works of art, including Buddhist icons.

The principal goal of the article is evaluating the peculiarities of Mongolian art in the context of ethnotraditions, as well as examining the influence of Central Asian cultures on the traditional Mongolianzurag and contemporary paintings. Keeping in line with the objectives, this research aims to probe the ethnic mentality of nomads and its importance for the formation of art; role of India's artistic traditions in the development of the fine arts of Mongolia; role of folk art in the formation and evolution of Mongolia's original painting; ethnic tradition in Mongolian contemporary art with the examples of creations of Zorig Uyanga, Lamjav Ganbold, Tugs-Oyun Sodnomyn, Gansukh Enkhtaivan, Zayasaykhan Sambuu.

\section{Theoretical Orientation}

The theoretical basis of the article includes the works of the researchers who consider the fine arts of Mongolia in the historical-cultural context: S.F. Oldenburg, G.Ts. Tsybikov, T.M. Stepanskaya, as well as their genesis and the process of evolution, highlighting distinctive ethnic traditions in them: B. Spuler, B.-A. Ruppen, A.N. Turunov, N.V. Kocheshkov, N.N. Belsky, N.-O.Tsultem, I.I. Lomakina, T.V. Sergeeva, and A.V. Rinchen-Khabaeva. Let us analyse the basic concepts and views of these scientists.

S.F. Oldenburg attached great importance to the study of art and noted its important role along with philosophy and history. In his works "Images of 300 Idols of Buddha" (Oldenburg, 1903a), "Album of Buddhist images of the Kazan Theological Academy" (Oldenburg, 1903b), "Materials on Buddhist iconography" (Oldenburg, 1914), "The first Buddhist exhibition in St. Petersburg" (Oldenburg, 1919), the monuments of Buddhist icon painting were first published and attributed, many works of Buddhist art, which had become examples of the original creativity of Mongolian masters, were introduced into scientific discourse. 
Oldenburg speaks of the originality of Mongolian art in terms of its ethnic identification, while a researcher G.Ts. Tsybikov in his work "Zonghava and his essay "Lamromchyn-po" notes that culture and Buddhist art have been borrowed from Tibet (Tsybikov, 1981). The lack of ethnic originality of Mongolian art is noted by Berthold Spuler. In the work "The Golden Horde. The Mongols in Russia:1223-1502", he writes as follows:

Art, as well as science, developed in the Golden Horde under the influence from abroad. Foreign ideas fell on fertile soil because the Tatars were gifted people. Their ability to adopt the best became evident right after the conquest of the Kypchak (Spuler, 2017: 375).

An American scientist, Robert Arthur Ruppen speaks about the lack of the Nomads' own culture (Ruppen, 2004). A.N. Turunovemphasises the excessive influence of Lamaism on the Mongols' art, the lack of the independent artistic merit and national identity (Turunov, 1922). However, it is incorrect to say that the Mongolians fully borrowed fine arts, since before the active cultural contacts with Tibet and China, the art of Mongolia had its own characteristics and features and in the process of assimilation with the introduced artistic experience, it acquired its original features. Thisis evidenced by numerous works of scientists of the 20th century. The thorough analysis of traditions in Mongolian art is presented in the work of N.V. Kocheshkov"The national art of the Mongols" (Kocheshkov, 1973). The author considers the evolution of Mongolian creativity on a broad historical background in close connection with the history of the people, with the development of its culture. N.N. Belsky in the work "Fine Arts of Mongolia" raises an issue of the necessity of studying the Mongolian art and especially ornaments, notes an important role of technical-artistic traditions developed by the collective genius of the people (Belsky, 1941). The monograph by Nyam-Osoryn Tsultem titled "The art of Mongolia from the ancient times to the beginning of the 20th century" (Tsultem,
1984) is a fundamental work addressing the issues of the history of Mongolian fine arts, in which the author considered the problem of formation and development of Mongolian art with the use of source data from archeology, philology, ethnography, as well as by analysing the unique collections of museums of the Mongolian People's Republic. The problems of synthesis of European painting and the traditional planar painting have found coverage in the studies of I.I. Lomakina "Fine Arts of Socialist Mongolia" (Lomakina, 1970) and in the monograph "MarzanSharav" (Lomakina, 1974). The problems of development of Mongolian painting from the Middle Ages to the contemporary period are presented in a number of works of a specialist in Mongolian studies T.V. Sergeeva (Sergeeva, 1992). The study conducted by O.S. Prokofiev"Contemporary art of the socialist countries of the East" emphasises the decisive role of the national style, as well as the influence of Western European realism, which is associated with the flowering of culture (Prokofiev, 1961). The history of Mongolian fine arts in the period of 1980-1990 is presented in the work of A.V. Rinchen-Khabaeva "Fine arts of the country of the eternal blue sky", where the author places the articles about the original creativity of Mongolian artists in chronological order (Rinchen-Khabaeva, 2005). Mongolian fine arts of the 20th century in the context of the influence of the Russian art school were considered by Altai art critics K.A. Melekhova and T.M. Stepanskaya (Melekhova \& Stepanskaya, 2013). Thus, the historiographic situation shows a broad research interest in fine arts of Mongolia and makes the study of ethnic traditions in painting relevant and scientifically significant.

\section{Methods}

The topic of the study of ethnic traditions in Mongolian fine arts determined the choice of the research methods. A comprehensive approach to the problem under study provided the objectivity of the work. Basic theoretical and practical research approaches were usedin the study, namely the methods of system, 
structural-functional, comparative-typological analysis, the methods of classical art history, as well as the formal stylistic, semiotichermeneutic and iconological methods of interpretation of cultural and art phenomena. These research methods are aimed at studying the features of the fine arts of Mongolia, which were formed and developed under the conditions of underlying multiculturalism, namely the interaction with other cultures of Central Asia and India, the unity of diverse constituent elements. They also help to interpret the specific conditions that give rise to specific patterns in the development of historical and cultural space. The methods make it possible to expand the problems of analysis of works of fine art and introduce works of art that have not been studied before into the scientific circulation. The method of stylistic analysis allowed considering the features of Mongolian painting through the example of artworks of contemporary Mongolian painters.

\section{Discussion}

The following part of the article is devoted to a multifaceted consideration of the issues of the formation and development of the fine arts of Mongolia in the context of the historical and cultural situation.

\section{The ethnic mentality of nomads and its importance for the formation of the art}

Mongolian fine art is a bright, distinctive link in the world artistic context. It is based on ethnic traditions and integrative artistic experience. The author of the monograph entitled "Ethnic tradition in modern humanitarian knowledge"

\section{L.I. Nekhvyadovich notes as follows:}

Traditions are not only a stable "framework of the nation", but also a necessary condition for its renewal. The preservation of ethnocultural diversity, the dialogue and interaction of unique national traditions are the basis of civilisation stability of mankind and its evolutionary cultural potential (Nekhvyadovich, 2014: 7).

Researchers refer Mongolian culture to the nomadic (steppe) type, which was developedon the basis of the traditional nature of the whole lifestyle based on the consistency of centuriesold homemaking skills, the commonality of worldviews of successive steppe peoples, their linguistic unity and the continuity of forms of culture. The diversity of culture is based on a complex system of relationships and, consequently, the interpenetration of the artistic experience of nomadic tribes of the Turkic peoples: the Huns, the Juan-Juan, the Turks-Tyugo, the Uighurs, the Kyrgyz, the Khitan, the Jurchen, etc. The integration and assimilation of artistic experience took place in the context of this ethnocultural diversity and resulted in a unique type of Mongolian culture. The artisticexperience of nomads was based on increased decorativeness. Household items, dwelling and costumes were richly decorated with ornaments. Ornamentality has become an important quality of the Mongols' art. If we analyse the genesis of the Mongolian ornament, the development of its artistic features, we may derive at the conclusion that the ornament, gradually developing and assimilating, is interpreted in a new way, in accordance with the cultural-historical context. Kocheshkov N.V. sees the peculiarity of the ornament in the dynamism of decorative compositions:

The restless, dynamic rhythm of compositions is enhanced by rapidly curling, intertwining curls of patterns. The peculiarity of each ornamental composition is that it unites separate patterns, which, at first glance, are scattered in a chaotic disorder, into a single strict artistic system, and thereby gives the patterns a certain sense (Kocheshkov, 1973: 18-19).

The ornament evolves from the archetypal, protective-decorative origin to the bright original artistic principle, on the basis of which the composition is formed. Ornamentality as a stylistic property was clearly manifested in the works of artists of the older generation - D. Manibazar, W. Yadamsuren, A. Sengezokhio, Ts. Minzhur, and others.

The role of Indian artistic traditions in the development of the fine arts of Mongolia 
Religious painting on scrolls is a bright artistic phenomenon based on the strict canon developed in India and inherited by many cultures of Asia. Means of artistic expressiveness, iconography, and a system of proportions developed in the depths of Indian civilisation. Religious painting on scrolls was based on a complex philosophical and religious doctrine of Buddhism, which originated in India and came to Mongolia through Tibetan monastic schools (Adygezalova, Alekseev, Antropova, Melekhova, \& Stepanskaya, 2010). Mongolian masters got acquainted with this artistic system and created an original style and their own logic of artistic perception on this basis. An artistic style characterised by a clear and bright colour range, an abundance of ornamental motifs, canons of a conventional two-dimensional calligraphic image, finest detailing, almost naturalistic and simultaneously scarcely perceptible conditionality and generality was created as a result of the combination of an ornamental pictorial technique, born in the depths of nomadic culture, with the methods of painting developed by sedentary peoples of India and Tibet. In comparison with Indian and Tibetan painting, Mongolian painting is more decorative. A researcher T.V. Sergeeva notes as follows:

Painting on scrolls, based on the iconographic medieval canon, progressively developing, by the end of the $19^{\text {th }}$ - the beginning of the $20^{\text {th }}$ century acquired new interpretation and new expression in accordance with the requests of the time. Painting on scrolls is the material embodiment of the synthesis of arts: graphics, calligraphy, literature, which had an initial connection with architecture, sculpture, theatrical-ritual mysteries. The historical-artistic interpretation of the works of art reveals not only their formal-stylistic unity, features inherent in the national cultural tradition, but also represents them as cultural phenomena of the time, prepared and legalised by the whole logic of the historical development of Mongolian society (Sergeeva, 1992: 4-5).
A tradition of working not from nature, but on the samplewas borrowed from India; therefore, an artist had well-developed visual memory. In Indian and Tibetan monasteries, artists honed the skills of perception and depiction of the image in a true copy of the original. This method of copying made it possible to actively develop professional artistic skills and painting techniques. At the same time, working on sample did not imply blind patterning. The artist's emotions and memories were woven into the iconographic basis. Thus, the traditional canonical formula did not prevail and a new work of art with the original solution was created, in which the composition was conditioned by new nuances, free rhythms and a characteristic live colour. Painting on scrolls gradually acquired the national character, stylistics approximating to folk art, ethnic elements and became an original phenomenon in artistic practice. These features were most clearly embodied in the works of Dzanabadzar, Zhugder, D. Damdinsuren, and MarzanSharav.

\section{Role of folk art in the formation and development of Mongolian original painting}

Ethnic features were manifestedin the most expressive way in folk art, which was not connected with the iconographic canon. Artists bravely expressed the features of gestures, facial expressions, characteristic costume details, and ethnographic features. There were conditionality and generality in images, but these factors were compensated by the freedom of interpretation, vitality, dynamic modelling of the form. Pictures "dzagal" and "uychir" were the most common among the works of folk art. Their artistic interpretation was characterised by spontaneity, observation, grace and rich creative imagination. The traditions of folk art organically became the basis for the formation and development of a new artistic direction "Mongol Zurag" in the 20th century. Mongol Zuragis based on the technique of traditional planar painting with glue, mineral and earth paints on a finegrainedprimed canvas. Gouache is often used as paint. Mongol Zurag compositions are characterised by clear planning, flatness of 
construction, lack of linear perspective and clear obscure. A picture is precise and accurate with the use of local bright saturated colour patches. The background is conditional and generalised. Great importance is given to decorative framing, which is performed on motives of Mongolian folk ornaments with complex symbolism. Prominent representatives of the Mongol Zurag artistic direction are as follows: U. Yadamsuren, A. Sengetsokhio, B. Gombosuren, B. Avarzad, Ts. Minzhuur, Ts. Zhamsoran, and others. At the end of the 20th century, an innovative interpretation of traditional painting "Mongol Zurag" appeared in Mongolian fine arts. Folklore plots, the figurative painting system, the means of artistic expressiveness, the technique and method of painting acquired new qualities. The prominence of the decorative origin increased; it was evident in the dominating value of colour composition, linearity, and ornamentality. Artists used not only folk stories and motives in their works, but also began to address artistic issues within the framework of aesthetics of postmodernism (the art of the second half of the $X X$ - the beginning of the XXI century) while not losing their ethnic identity. These are Mongolian artists N.-O. Tsultem, O. Myagmar, P. Tsogzol, C. Ichinnorov, E. Ulzijkhutag, Ch. Khurelbaatar, and others.

Ethnic traditions in Mongolian contemporary fine arts with the examples of creations of Zorig Uyanga, Lamjav Ganbold, Tugs-Oyun Sodnomyn, Gansukh Enkhtaivan, Zayasaykhan Sambuu

Contemporary fine arts of Mongolia are a vivid example of synthesised artistic experience, where traditions and innovations are organically combined in creativity. The creative method of contemporary artists proves that despite working in various directions, genres, techniques, individual manners, all of them remain deeply national. This thesis can be argued by considering the works of contemporary Mongolian artists. Zorig Uyangais a graphic artist, painter, teacher, and the chairman of the Union of Designers of Mongolia. An ethnic element in her works is manifested both in the choice of the plot and in traditional means of artistic expressiveness. Zorig Uyanga's creative method is a synthesis of the traditional and the innovative. Uyanga's works are characterised by the warmth of colour, pictorial refinement, and compositional rhythm. The favourite topics of creativity were folklore images, ancient legends, tales, the history of Mongolia, as well as female images, theatrical backstage, ballet, etc. Her art is symbolic and full of profound meaning. In graphic and pictorial images, which are comprehended by the artist in her own way, the eternal issues of comprehension of the meaning of life, spiritual perfection, and the continuity of generations are raised. The main means of artistic expressiveness for the artist is a line that has many variations; this line expresses the main idea of the work of art. Zorig Uyanga conveys new compositional graphic forms by means ofstylisation and generalisation. As a rule, the background remains neutral, the context is not important, the image is in the first place. Colour is also a certain symbol, an original category of the idea of the work. These qualities are similar to traditional Mongolian painting- Mongol Zurag. The author hones a technique of execution to perfection through the analytical perception of the model. These features have been manifested in a series of etchings - "Lady" (2001), works "Mother of Heaven" (2005), "Bride" (2005), "Silence" (2006), in a series dedicated to ballet (2009). Uyanga's creativity is a vivid example of the manifestation of ethnocultural traditions in contemporary fine arts. Lamjav Ganbold is a Mongolian painter whose creativity characterises the generation of artists who created their own unique style by combining the traditional direction- "Mongol Zurag" and the European painting school. The Russian Academy of Arts and Yuri Mikhailovich Neprintsev, who was the main mentor in painting for Ganbold, played an important role in the formation of the artist's creative method. Even as a student, he learned a wide range of means of artistic expressiveness and developed compositional thinking based on the European method of working from nature. This allowed 
the artist to become a master of landscape painting with his own pictorial manner. National identity in his creativity was already apparent in the 1990s. Lamjav Ganbold's creativity illustrates the development of decorative trends in Mongolian painting. His works are full of colouristic sound, active movement. Dynamics increases with the rhythm of the image-compositional system. This artistic technique gives the artist's works expressiveness and musicality. In "Autumn" (1998), "Before the Rain" (2004), "First Snow" (2005), "Pink Evening" (2005) and in other works there are romantic trends. In these works, the artist rises to the generalised poetic image of nature in its various states. Bright, energetic, pastose painting is associated with decorative-impressionistic strivings. The paintings "Moonlit Night" (1998), "Night Serenade" (2004), "Evening" (2005) are characterised by intensive colours and poeticmusical mood. Plastic strokes of paints reflect in a sonorous blue range. This creates a feeling of fantasy, mystery, fabulousness. The household topic is covered by the author in his own way. The landscape depicting people performing the activities usual for arats (Mongolian herdsmen) is typical of Mongolian artists. Ganbold forms these plots not by depicting specific characteristics of household activities, but through the presentation of his feeling of charm with the steppe life in harmony with nature - inaccessible mountains, boundless steppe, azure sky. Such are the artist's works - "Evening in Uri" (2004), "New Nomad Camp" (2004), "First Frost" (2005), etc. Epicism and the major mode are felt in mountain landscapes: "Rocky Ensemble" (2000), "Noon in the Gorge" (2005). In these paintings, colour harmony is echoed by the compositional and rhythmic order. The artist forms the ornamental motif through chord succession. This creates a sense of grandeur and monumentality, admiration and reverence for mountains. The artist's creative method is unique. His canvases reveal the character of the Mongolian people, ethnocultural traditions, and artistic values. L. Ganbold represents Mongolia in bright, sonorous, bold colouring.
He depicts nature as he sees it - extraordinary, fascinating, and amazing. The national criteria of artistry are revealed in his creativity through generalisation, the graphic structure, decorativeness, and the colour palette. Ganbold's creativity is based on the national outlook and traditions of the Russian artistic academic school. He creates his artistic space and does not lose his national identity.

The creativity of a Mongolian artist TugsOyunSodnomyn confirms the fact that Mongolian folk traditions fit perfectly into contemporary art life. They are a living, inexhaustible, constant source of inspiration for the formation of an original style. Her artistic approach was formed under the influence of several trends in art: European symbolism and primitivism, as well as traditional Mongolian planar painting. Drawing, a stroke, a line are the main means of artistic expressiveness. A precise, bold, plastic line reveals imagessymbols, graphically divides the space into parts. A special creative method allows the artist to freely use any topic and remain recognisable. The traditional principles of frontlocal national painting vary, develop, and acquire new qualities. Such are the following works: "The Beauty of the Gobi" (1986), "Prayer" (1996), "Meeting in the Gobi" (1996), "Eternal Love" (1997), "Young Camels" (2005), "Love in the Gobi" (2005), "Three Ladies" (2005). As a master, Tugs-Oyun found her images of man and nature and developed her techniques of their pictorial embodiment.

Gansukh Enkhtaivan is a young and original artist of Mongolia, whose creativity clearly shows an individual style and a bright ethnic background. The artistic embodiment of images in Enkhtaivan's works is harmonious and permeated with a personal natural hedonistic ability to contemplate nature, for expression of which the artist used the national pictorial tradition and professional art school. In the artist's creativity, the landscape prevails, in which the author finds various kinds, states, moods. The works "Oasis" (2013), "Lake in the Evening" (2014) are devoted to the image of the Gobi, a plot typical for the creativity of the Mongols. In the author's interpretation, this 
motive is decorative. The artist expresses the idea of the infinite space of the universe of nomads through a bright colouristic approach, an open compositional solution, clarity, even through the placement of plans by rows. The works "The Power of Mountains" (2014), "Origins" (2014) are devoted to the image of mountains, which is another symbol of national mentality. Epicism, striving for monumentality and decorativeness are conveyed by means ofgeneralisation, universalisation of the image by colour and light. The landscape compositions "The Mighty Man", "Mongolian Symbols", "Naadom Festival" are supplemented by genre motifs. And here we can also notice national archetypes - the images of a horse, riders, yurts. These images are characterised by the laconicity of colour composition, generality, the applicability of details, and the predominance of the close-up view - traditional techniques of the Mongolian figurative system. G. Enkhtaivan's works are characterised by confident pastose strokes, open compositional structure, conditionality of figures. Bright blue, juicy green, deep red are the prevailing palette, which activates the viewer's attention. The decorativeness of artistic techniques emphasises the adherence to national fine arts. Zayasaikhan Sambuu is a modern Mongolian artist who was born in a small nomad camp in the Gobi Desert in the West of Mongolia, received professional education at the Faculty of Painting at the Mongolian University of Culture and Art, currently lives in California and works at the International Artist Community (Mongolian artist. Zayasaikhan Sambuu, n. d.). The search for an individual creative manner led Z. Sambuu to study the ethnocultural heritage of the Mongols. Symbolic images of national beauties in traditional costumes, with luxurious jewelry, complex headdresses and hairstyles are typical of his works. Images tend towards iconography, which originates in national traditions of Mongolian religious painting on scrolls and in folk art. The artist acts on his canvases as a successor of the best artistic traditions of his culture. Developing traditional methods of depiction, he resorts to techniques of conditional generaliseddepiction and brightlycoloured planar painting. His interests as an artist are focused on the expression of colourful harmony, the colourful integrity of the canvas.

\section{Conclusion}

In general, we can identify the main features of manifestation of ethnic traditions in fine arts of Mongolia. Firstly, an important role is played by ethnic mentality, in which certain patterns in stylistics of art - decorativeness, universality, and ornamentality - are developed at the conscious and unconscious levels. Secondly, the influence of the traditions of sedentary cultures, in particular, the Indian ones, on the development of ethnic features led to the emergence of the concept of an artistic system in Mongolian art, as well as introduced to the artistic experience of Central Asian cultures. The acquaintance with the Buddhist canon brought Mongol art to a higher level and allowed Mongolian artists to master a new process of creativity, which was aimed at expressing the internal "spiritual vision", not at recreating the surrounding world. The traditional formula of the canon did not dominate the consciousness of an icon painter and, in this case, the borrowed artistic experience acquired distinctive features. Thirdly, the ethnic origin manifested in folk art formed the basis for the unique artistic direction- "Mongol Zurag" and brought the fine arts of Mongolia to the world level. Fourthly, in modern art, the ethnic tradition found its expression through the archetypal origin, myth-making, national symbols, images, plots, traditional artistic techniques. Thus, the Mongolian art has deep distinctive traditions that were formed in the past and developed in contemporary painting. Ethnic traditions formed the basis of the artistic-imaginative system and became a source for the formation of the creative method of artists in different historical periods.

\section{References}

Adygezalova, G.E., Alekseev, A.A., Antropova, N.K., Melekhova, K.A., \&Stepanskaya, T.M. (2010). Integratsionnyeprotsessy v kulture: 
Opytvliyaniyarusskoikhudozhestvennoishk olynarazvitieiskusstvaMongolii v XX veke [Integration processes in culture:

Experience of the influence of the Russian artschool on the development of Mongolian art in the 20th century]. In Gumanitarnyeproblemysovremennosti: Chelovekiobshchestvo. Novosibirsk, Russia.

Belsky, N.N. (1941).

IzobrazitelnoeiskusstvoMongolii [Fine arts of Mongolia]. SovremennayaMongoliya, 23, 12-16.

Kocheshkov, N.V. (1973). Narodnoeiskusstvomongolov [Folk art of the Mongols]. Moscow, USSR: Nauka.

Lomakina, I.I. (1970). IzobrazitelnoeiskusstvosotsialisticheskoiMo ngolii [Fine arts of socialist Mongolia]. Ulan-Bator, Mongolia: Gosizdatelstvo.

Lomakina, I.I. (1974). MarzanSharav [MarzanSharav]. Moscow, USSR: Izobrazitelnoeiskusstvo.

Melekhova, K.A., \&Stepanskaya, T.M. (2013). Russian art school in the process of integration of Western and Eastern cultures (XX - beginning of XXI century). Middle-East Journal of Scientific Research, 15(1), 87-93.

Nekhvyadovich, L.I. (2014). The possibilities of ethnomethodology in modern art studies. Terra Sebus: ActaMuseiSabesiensis, Special Issue, 187-199.

Mongolskiikhudozhnik. ZayasaikhanSambuu [Mongolian artist. ZayasaikhanSambuu]. (n. d.). Retrieved September 5, 2017, from http://www.risunoc.com/2013/03/mongol skiy-khudozhnik-zayasaikhansambuu.html.

Oldenburg, S.F. (1903a). Izobrazheniya 300 burkhanov [Images of 300 idols of Buddha]. St. Petersburg, Russia: Tipografiya Imperatorskoi Akademii Nauk.

Oldenburg, S.F. (1903b). AlbombuddiiskikhizobrazheniiKazanskoiDu khovnoiAkademii [Album of Buddhist images of the Kazan Theological Academy]. St. Petersburg, Russia.

Oldenburg, S.F. (1914).

Materialypobuddiiskoiikonografii

[Materials on buddhist iconography]. In Volkov, F.K. (Ed.),

MaterialypoetnografiiRossii (vol. 2). St. Petersburg, Russia.

Oldenburg, S.F. (1919).

Pervayabuddiiskayavystavka v Peterburge

[The first Buddhist exhibition in St.

Petersburg]. St. Petersburg, USSR:

Department for Museums and the Protection of Monuments of Art and Antiquities.

Pozdneev, A.M. (1993).

Ocherkibytabuddiiskikhmonastyreiibuddiisk ogodukhovenstva $v$ Mongolii v svyazi s otnosheniyami sego poslednego $k$ narodu [Sketches of the everyday life of buddhist monasteries and the buddhist clergy in Mongolia in connection with the relationship of the latter with the people]. Elista, Russia:

Kalmytskoeknizhnoeizdatelstvo.

Prokofiev, O.S. (1961).

Sovremennoeiskusstvosotsialisticheskikhstr anVostoka [Contemporary art of socialist countries of the East]. Moscow, USSR: IzdatelstvoAkademiikhudozhestv SSSR.

Puchkovsky, L.S. (1960).

AleksandrVasilievichlgumnov (1761-1834). In

Ocherkipoistoriirusskogovostokovedeniya (vol. 3, pp. 166-195). Moscow, USSR: Izdatelstvovostochnoiliteratury.

Rinchen-Khabaeva, A.V. (2005). Izobrazitelnoeiskusstvostranyvechnogosine goneba [Fine arts of the land of the eternal blue sky]. Ulan-Ude, Russia:

IzdatelstvoBuryatskogogosudarstvennogou niversiteta.

Ruppen, R.A. (2004). Mongolydvadtsatogoveka [Mongols of the 20th century]. Ulan-Ude, Russia: Publishing House of BSC SB RAS. 
Sergeeva, T.V. (1992). IskusstvoMongolii [The art of Mongolia]. Moscow, Russia: IzdatelstvoGosudarstvennogomuzeyaiskuss tvanarodovVostoka "Sorek-Poligrafiya".

Spuler, B. (2017). ZolotayaOrda. MongolynaRusi (1223-1502) [Golden Horde. The Mongols in Russia (12231502)]. Moscow, Russia: ZAO Tsentrpoligraf.

Tsultem, N.O. (1984). The art of Mongolia from the ancient times to the beginning of the 20th century. Moscow, USSR.
Tsybikov, G.T. (1981). Tszonkhavai ego sochinenie "Lam-rim chyn-po" [Zonghava and his essay "Lam-rim chyn-po"]. In Izbrannyetrudy (vol. 2, pp. 169-176). Novosibirsk, USSR.

Turunov, A.N. (1922). Proshloeburyatmongolskoinarodnosti: Populyarnyiistorikoetnologicheskiiocherk [The past of the Buryat-Mongolian nationality: Popular historical and ethnological essay]. Irkutsk, USSR: Gosudarstvennayatipografiya. 